\title{
STABILITAS ZAT WARNA ANTOSIANIN BIJI KAKAO PADA BERBAGAI KONDISI KOPIGMENTASI
}

\author{
Stability of Cocoa Beans Anthocyanin Pigmen in Various Copigmentation Conditions \\ Justus Elisa Loppies, Khaerunnisa, Endang Sri Rejeki, Medan Yumas, dan Alfrida \\ Lullung.S. \\ Balai Besar Industri Hasil Perkebunan \\ JI. Prof. Dr. Abdurahman Basalamah No. 28, Makassar 90231 \\ email: justusloppies@gmail.com
}

\begin{abstract}
Anthocyanins are classified as pigmented compounds found in cocoa beans. This compound has an unstable color and is easily degraded by acidity, lighting, temperature, oxidation and handling processes. To achieve stability, anthocyanins need to be controlled by the copigmentation method, ie by reacting the reinforcing material as copigment with anthocyanins so that they are not easily degraded. The material used for the copigmentation of the cocoa beans anthocyanin is gallic acid with a ratio of 1:0;1:1; 1:2 dan 1:3 which was treated with a temperature of $60 ; 70 ; 80$ and $90{ }^{\circ} \mathrm{C}$ for 30 minutes. The results showed that the anthocyanin extracts copigmented with gallic acid 1:2 and 1:3 can prevent the color instability at $60-70{ }^{\circ} \mathrm{C}$. The copigmentation effect produces color with high intensity and stability compared to non-copigmented anthocyanins. The highest intensity is 0.336-0.387 at a temperature of 60-70 ${ }^{\circ} \mathrm{C}$ with a brightness $(L *)$ of 22.63 at a ratio of $1: 1$. The dominant color is reddish (a *) more than yellowish $\left(b^{*}\right)$ occurs at a ratio of 1: 2 with a value of 12.37 and 8.6. The smallest color change $(\Delta E)$ is 66.93-67.15 at a ratio of $1: 1$ and 1: 2 .
\end{abstract}

Keywords: stability, anthocyanin pigments, cocoa beans, copigmentation.

Abstrak: Antosianin tergolong senyawa berpigmen yang terkandung dalam biji kakao. Senyawa ini memiliki warna yang tidak stabil dan mudah terdegradasi oleh faktor keasaman, pencahayaan, suhu, oksidasi maupun proses penanganan. Untuk mencapai kestabilan, antosinanin perlu dikendalikan dengan metode kopigmentasi yaitu dengan mereaksikan bahan penguat sebagai kopigmen dengan antosianin agar tidak mudah terdegradasi. Bahan yang digunakan untuk kopigmentasi antosianin biji kakao adalah asam galat dengan rasio perbandingan 1:0; 1:1; 1:2 dan 1:3 yang diberi perlakuan suhu 60; $70 ; 80$ dan $90{ }^{\circ} \mathrm{C}$ selama 30 menit. Hasil penelitian menunjukkan bahwa ekstrak antosinin yang dikopigmen dengan asam galat 1:2 dan 1:3 dapat mengatasi instabilitas warna pada suhu $60-70{ }^{\circ} \mathrm{C}$. Efek kopigmentasi menghasilkan warna dengan intensitas yang tinggi dan stabil dibanding dengan antosianin yang tidak dikopigmentasi. Intensitas tertinggi adalah $0,336-0,387$ pada suhu $60-70{ }^{\circ} \mathrm{C}$ dengan kecerahan $\left(L^{*}\right)$ 22,63 pada rasio 1:1. Warna dominan adalah kemerahan $\left(a^{*}\right)$ melebihi kekuningan $\left(b^{*}\right)$ terjadi pada rasio 1:2 dengan nilai 12,37 dan 8,6. Pergeseran warna terkecil $(\Delta E)$ adalah 66,93-67,15 pada rasio 1:1 dan 1:2.

Kata Kunci: stabilitas, pigmen antosianin, biji kakao, kopigmentasi

\section{PENDAHULUAN}

Kestabilan dan intensitas warna merupakan faktor penentu terhadap ketertarikan dan kualitas suatu produk terutama produk pangan. Upaya untuk menghasilkan suatu produk melalui sentuhan warna agar lebih menarik sering membuat produsen menggunakan bahan pewarna sintetik yang memiliki intensitas warna yang kuat, lebih stabil dan murah. Permasalahan yang terjadi adalah beberapa kasus gangguan kesehatan yang diakibatkan terlalu sering mengkonsumsi produk pangan atau minuman yang menggunakan pewarna sintetik. Efek karsinogenik yang ditimbulkan dari penggunaan pewarna sintetik menyebabkan konsumen cenderung beralih ke produk-produk yang menggunakan pewarna yang bersifat alami. Salah satu bahan pewarna alami yang perpotensi dijadikan alternatif pengganti bahan pewarna sintetik adalah antosianin. 
Antosianin tergolong ke dalam pigmen larut air yang berperan sebagai pemberi warna bunga, buah dan daun pada berbagai jenis tanaman. Senyawa ini termasuk sub-tipe senyawa organik dari keluarga flavonoid, dan merupakan bagian dari kelompok senyawa yang lebih besar yaitu polifenol (Houghton dan Hendry, 2012). Senyawa ini bersifat amfoter yaitu dapat bereaksi dalam kondisi asam maupun basa. Dalam kondisi asam, antosianin membentuk warna merah dan dalam suasana basa membentuk warna ungu atau biru (De Man, 1997). Keragaman antosianin menyebabkan warna yang dihasilkanpun berbeda-beda, hal ini terkait dengan adanya perbedaan gugus pada struktur dasarnya (Brouillard, 1982).

Beberapa tanaman seperti anggur, teh, manggis telah diekstrak untuk mendapatkan pigmen antosianin sebagai pewarna pangan. Selain dari jenis-jenis tanaman tersebut, pigmen antosianin juga terdapat dalam jaringan tanaman kakao sehingga sangat potensial untuk dikembangkan sebagai sumber pewarna alami. Bagian tanaman kakao yang mengandung senyawa pigmen antosianin terdapat pada jaringan kulit buah dan biji. Biji kakao mengandung sekitar 5-18\% senyawa polifenol seperti katekin dan antosianin, dengan kandungan antosianin sekitar 5\% (Misnawi et al., 2003)

Pemanfaatan antosianin dari biji kakao sebagai pewarna masih kurang diteliti dibanding dengan kulit buahnya, hal ini disebabkan karena biji kakao dinilai lebih ekonomis jika dimanfaatkan sebagai produk pangan terutama dalam bentuk produk intermediate seperti liquor dan bubuk dengan nilia jual yang lebih tinggi. Namun sebagai dasar untuk memanfaatkan antosianin dari biji kakao adalah fungsi pigmennya yang tidak sekedar sebagai bahan pewarna, tetapi merupakan senyawa fungsional yang memiliki fungsi kesehatan terutama pada makanan, minuman kesehatan dan produk farmasi dengan manfaat yang lebih tinggi. Ekstraksi pigmen antosianin dari kakao telah dilakukan oleh (Sampebarra, 2018) dengan menggunakan etanol dan asam (asam asetat dan asam oksalat) pada suhu 40$60{ }^{\circ} \mathrm{C}$, diperoleh pigmen antosianin yang belum stabil atau dengan intensitas warna yang masih lemah yaitu 0,158 0,207 .

Ketidakstabilan pigmen antosianin dipengaruhi oleh beberapa faktor antara lain: $\mathrm{pH}$, temperatur, keberadaan oksigen $\left(\mathrm{O}_{2}\right)$ dan $\mathrm{H}_{2} \mathrm{O}_{2}$ dan cahaya (Basuki et al., 2005 dalam Samber et al., (2013)). Pigmen antosianin memiliki intensitas yang kuat dalam kondisi asam, tetapi terdegradasi dan tidak berwarna dengan adanya cahaya, kenaikan suhu dan oksidasi (DelgadoVargas dan Paredes-Lopez, 2002; Nusantara et al., 2017), Lydia et al. (2001), (Siregar dan Nurlela, 2011).

Kopigmentasi antosianin merupakan solusi untuk mempertahankan kestabilan antosianin pada berbagai kondisi perlakuan maupun dalam aplikasinya ke berbagai produk industri. Beberapa metode yang digunakan untuk melakukan kopigmentasi antosianin antara lain: dengan mengkombinasikan senyawa lain atau antara senyawa pigmen itu sendiri, sehingga membentuk suatu ikatan atau formulasi baru dengan sifatsifat yang lebih stabil. Mekanisme interaksinya dapat terjadi melalui ikatan intermolekul, intramolekul, kompleks dengan logam atau antar molar senyawa itu sendiri (Castañeda-Ovando et al., 2009).

Upaya untuk meningkatkan kestabilan pigmen antosianin dalam riset ini adalah dengan menggunakan metode kopigmentasi yaitu suatu metode penataan atau formulasi pigmen antosianin dengan asam galat untuk menghasilkan suatu sediaan zat warna yang lebih stabil dan lebih mudah diaplikasikan. Penggunaan asam galat sebagai bahan kopigmen antosianin berkaitan dengan gugus hidroksil dengan elektron bebas yang berlebihan 
sehingga memungkinkan terjadinya transfer elektron ke molekul antosianin yang kekurangan elektron sehingga membentuk keseimbangan elektron (Castañeda-Ovando et al., 2009). Selain itu, asam galat juga berperan dalam menciptakan keasaman yang kuat sehingga antosianin yang terkopigmentasi menjadi lebih stabil.

Penelitian ini bertujuan untuk mengungkapkan penyebab dan upaya untuk mengatasi instabilitas pigmen antosianin melalui penguatan intensitas warna dan tingkat kecerahan pigmen antosianin dari biji kakao menggunakan metode kopigmentasi.

\section{METODOLOGI}

\section{Alat dan Bahan}

Alat-alat yang digunakan antara lain neraca analitik, alat-alat gelas laboratorium, rotary vacuum evaporator, oven, penangas air (Thermostatic waterbath, model HWS-24, merek Drawell, buatan Shanghai), $\mathrm{pH}$ meter, cawan penguap, spray dryier, ultra turrax digital, model T25D buatan Jerman, hot plate (Thermo, model No: SP88857105 merek Cimarec, buatan China), magnetic stirrer dan mixer.

Bahan-bahan yang digunakan untuk kopigmentasi pigmen antosianin terdiri dari: biji kakao kering tanpa fermentasi dengan kadar air $12 \%$, etanol $96 \%$, asam galat $\left(\mathrm{C}_{7} \mathrm{H}_{6} \mathrm{O}_{5}\right)$ dengan tingkat kelarutan $1,1 \mathrm{~g} / 100 \mathrm{ml}$ air, dan aquadest.

\footnotetext{
Metode

Penelitian ini dilaksanakan dengan metode percobaan pada skala laboratorium. Kegiatan penelitian dilaksanakan melalui kajian beberapa literatur, pelaksanaan penelitian yang meliputi: ekstraksi, reformulasi dengan metode kopigmentasi, enkapsulasi pigmen antosianin, dan analisis sifatsifat produk.

Tahapan Pelaksanaan Penelitian

Pelaksanaan penelitian dilakukan dalam tiga tahap yaitu: 1) penyiapan
}

massa kakao, 2) ekstraksi antosianin dari massa kakao, dan 3) kopigmentasi antosianin dengan asam galat.

\section{Penyiapan Massa Kakao}

Pada tahap ini, biji kakao kering tanpa fermentasi dengan kadar air sekitar $12 \%$ dan kadar lemak sekitar $50 \%$, dihancurkan hingga membentuk liquor dengan ukuran sekitar $20 \mu \mathrm{m}$, selanjutnya liquor dikempa pada tekanan $400 \mathrm{~kg} / \mathrm{cm}^{2}$ menggunakan hidraulic press pada suhu $65{ }^{\circ} \mathrm{C}$ yang bertujuan untuk mengeluarkan sejumlah lemak dari massa kakao, sehingga diperoleh hasil kempa yang disebut bungkil atau cake dengan kandungan lemak sekitar $15 \%$. Bagian bungkil atau cake ini merupakan sediaan dari hasil olahan biji kakao yang akan digunakan sebagai sumber penghasil antosianin.

\section{Ekstraksi Antosianin}

Ekstraksi antosianin dilakukan dengan cara maserasi massa kakao dalam bentuk bungkil atau cake menggunakan etanol 96\%. Proses maserasi dilakukan dengan cara merendam satu bagian massa kakao ke dalam 1,5 bagian etanol $96 \%$ dan kemudian disimpan selama 24 jam. Pada akhir maserasi diperoleh bagian cairan berwarna merah tua dan selanjutnya dipekatkan menggunakan alat rotary vacuum evaporator dengan tujuan untuk menguapkan sejumlah air dan etanol sehingga diperoleh massa pigmen cair berwarna merah pekat.

\section{Kopigmentasi Antosianin}

Kopigmentasi antosianin dilakukan secara intermolekul yaitu dengan menambahkan bahan yang mengandung gugus hidroksil seperti asam galat ke dalam pigmen antosianin. Kopigmentasi dilakukan dengan mencampurkan asam galat ke dalam pigmen antosianin dengan rasio perbandingan molar $1: 1, \quad 1: 2, \quad 1: 3$ dengan kontrol tanpa asam galat (1:0). Hasil kopigmentasi kemudian dipanaskan pada suhu $60,70,80$ dan $90{ }^{\circ} \mathrm{C}$ selama 30 menit. 
Pengujian Pigmen Antosianin

Parameter uji yang dilakukan untuk mengevaluasi hasil kopigmentasi pigmen antosianin meliputi analisis intensitas warna dengan metode spektrofotometer UV-VIS, tingkat kecerahan dan warna pigmen dengan metode chromameter.

\section{HASIL DAN PEMBAHASAN Intensitas Warna}

Intensitas warna merupakan salah satu parameter yang ditentukan berdasarkan panjang gelombang. Pentingnya pengukuran intensitas warna suatu bahan sediaan seperti antosianin berkaitan dengan aplikasi berkelanjutan terhadap barang atau produk yang akan diberi warna sehingga sifat-sifat yang dimiliki dari suatu sediaan zat warna dapat diketahui sehingga dapat disesuaikan dengan peruntukkannya.

Hasil analisis sediaan zat warna antosianin dari biji kakao yang dikopigmen dengan asam galat pada berbagai suhu (Gambar 1) menunjukkan bahwa pada suhu $60-90{ }^{\circ} \mathrm{C}$ terdapat perbedaan intensitas warna antosianin yang sangat kecil diantara perlakuan rasio molar antosianin dibanding asam galat 1:1, 1:2 dan 1:3. Intensitas warna ketiga rasio ini masih lebih tinggi dibanding dengan rasio antosianin yang tidak diberi perlakuan kopigmentasi. Hal ini menunjukkan bahwa daya absorbsi warna antosianin telah mencapai batas optimum dan stabil hingga mencapai suhu pemanasan $90{ }^{\circ} \mathrm{C}$. Berbeda dengan antosianin yang tidak mengalami kopigmentasi dimana, pada suhu $70{ }^{\circ} \mathrm{C}$ mulai terjadi degradasi hingga suhu $90{ }^{\circ} \mathrm{C}$ yang berakibat pada penurunan intensitas warna. Fenomena ini dijelaskan oleh Markakis (1982) bahwa, penurunan stabilitas warna antosianin disebabkan oleh dekomposisi antosianin dari bentuk aglikon menjadi kalkon yang tidak berwarna dimana pada suhu tinggi, ikatan glikosidik antosianin mengalami hidrolisis yang menghasilkan aglikon yang bersifat tidak stabil. Selain itu, ketidakstabilan antosianin pada perlakuan kontrol menunjukkan ketidakseimbangan $\mathrm{pH}$ dan susunan elektron sehingga menjadi labil ketika diberi atau tanpa perlakuan panas.

Kestabilan intensitas warna pada rasio antosianin yang diberi penguatan dengan bahan kopigmen menunjukkan bahwa telah terjadi keseimbangan pemenuhan kekurangan elektron oleh asam galat sebelum pemanasan. Interaksi yang terjadi adalah pembentukan senyawa kompleks secara intermolekul sehingga kestabilan intensitas warna dapat dipertahankan selama pemanasan.

Penguatan pigmen antosianin oleh asam galat hanya bersifat pemenuhan kekurangan elektron pada antosianin yang sangat mudah terdegradasi oleh keasaman $(\mathrm{pH})$, cahaya dan terutama oleh interaksi nukleofilik air yang terjadi secara intermolekul. Pada kasus ini, perlakuan dengan suhu $60-90{ }^{\circ} \mathrm{C}$ pada antosianin yang telah distabilkan dengan asam galat menyebabkan terjadinya degradasi sebagai akibat hidrolisis pada ikatan glikosidik antosianin.

Sedian zat warna antosianin yang dihasilkan dari penelitian ini telah melengkapi penelitian sebelumnya oleh Sampebarra (2018) yang melakukan ekstraksi etanol antosianin dari bahan yang sama dengan perlakuan suhu 40$60{ }^{\circ} \mathrm{C}$ dan menggunakan asam asetat dan asam oksalat pada $\mathrm{pH} 2-4$. Hasil intensitas warna yang diperoleh ratarata berkisar antara 0,158-0,207, sedangkan pada penelitian ini diperoleh rata-rata nilai intensitas warna pada berbagai perlakuan adalah 0,309-0,387. Hal ini menunjukkan bahwa, kopigmen antosianin dengan asam galat mampu membentuk kompleks intermolekul secara seimbang dan sempurna walaupun diproses dengan suhu di atas $60{ }^{\circ} \mathrm{C}$. 


\section{Tingkat Kecerahan dan Warna Pigmen Antosianin pada Berbagai Rasio Kopigmentasi}

Parameter tingkat kecerahan dan warna parameter ditentukan berdasarkan pantulan cahaya oleh permukaan sampel yang meliputi nilai tingkat kecerahan $\left(\mathrm{L}^{*}\right)$, tingkat kemerahan $\left(a^{*}\right)$, tingkat kekuningan $\left(b^{*}\right)$ dan tingkat perubahan warna secara keseluruhan $(E)$ (Hutching, 1999).

Hasil analisis tingkat kecerahan antosianin yang dikopigmentasi dengan asam galat menunjukkan perbedaan yang tidak mencolok diantara rasio perbandingan molar bahan kopigmen 1:1, 1:2 dan 1:3 (Gambar 2). Tampaknya pada rasio 1:2, menunjukkan tingkat kecerahan yang lebih tinggi dari perbandingan rasio lainnya, namun secara umum rata-rata tingkat kecerahan dari ketiga rasio tersebut hampir sama dan ketiga rasio ini memiliki nilia kecerahan yang lebih kuat dibanding dengan tingkat kecerahan pada perlakuan kontrol (rasio 1:0).

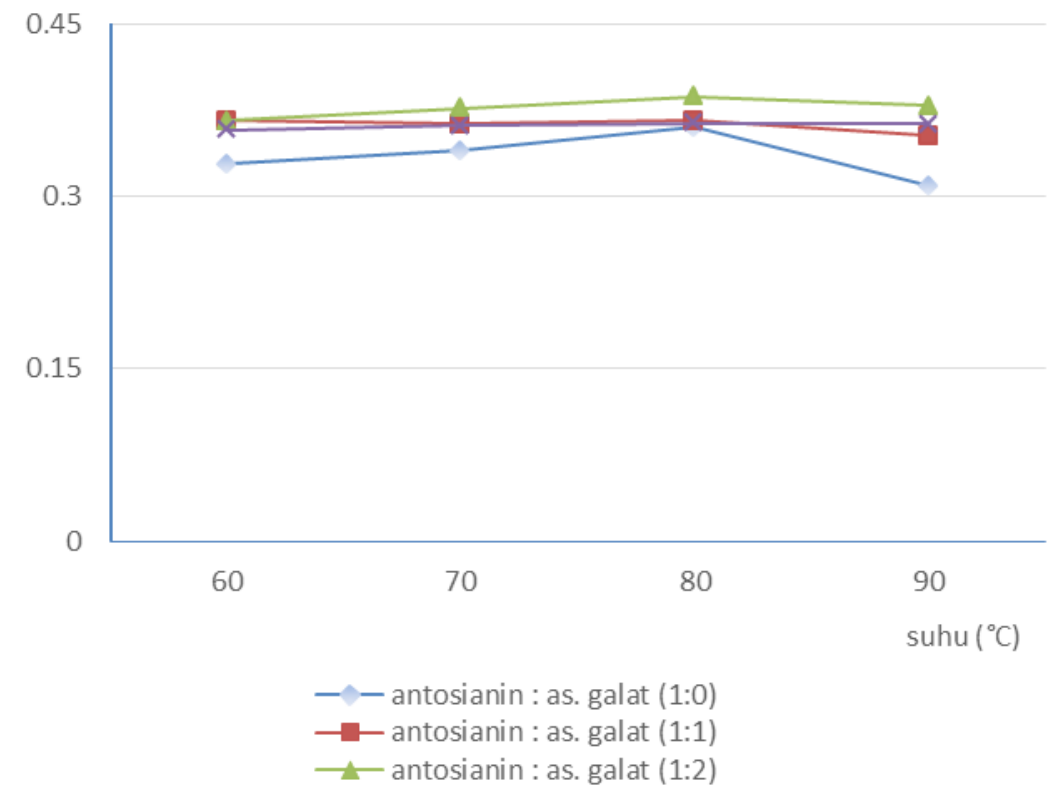

Gambar 1. Intensitas warna pigmen antosianin dari berbagai konsentrasi bahan kopigmen dan suhu.

Secara kromatik, spesifikasi warna yang dominan adalah tingkat kemerahan $\left(a^{*}\right)$ dan tingkat kekuningan $\left(b^{*}\right)$ juga dihasilkan oleh rasio $1: 1,1: 2$ dan 1:3. Hal ini menunjukkan bahwa kopigmentasi asam galat mampu memberikan efek yang kuat terhadap warna dasar kemerahan sampai kekuningan pada pigmen antosianin biji kakao.

Hal ini didukung oleh hasil pengukuran terhadap perubahan nilai warna secara keseluruhan $\left(\begin{array}{ll}\Delta & E\end{array}\right)$ (Gambar 3) dimana nilai total warna menunjukkan pola penurunan atau lebih rendah dari rasio kontrol. $\mathrm{Hal}$ ini menunjukkan bahwa telah terjadi pergeseran warna yang mencolok pada antosianin yang tidak diberi perlakuan kopigmentasi dengan asam galat dibanding dengan rasio lainnya.

Hunter (1952) dalam Hutching (1999), nilai "E" merupakan atribut nilai warna yang menjadi parameter terjadinya perubahan warna secara keseluruhan, dimana semakin tinggi nilai "E" menunjukkan semakin besar terjadi perubahan warna dan sebaliknya, nilai 
"E" yang rendah menunjukkan kecil terjadinya perubahan warna (lebih stabil). Dari kriteria ini dapat diungkap hasil analisis (Gambar 4), bahwa kopigmentasi asam galat mampu mengatasi efek pergeseran warna sebagai penyebab instabilitas antosianin. Secara umum dapat dinyatakan bahwa antosianin yang dihasilkan dari kopigmen asam galat dapat memberikan efek warna dan kecerahan yang tinggi dibanding dengan antosianin dengan tanpa kopigmen.

Fenomena kestabilan antosianin oleh interaksi dengan asam galat terjadi karena adanya pembentukan senyawa kompleks melalui mekanisme interaksi transfer elektron bebas atom oksigen pada gugus fenol atau karboksilat pada asam galat dengan molekul antosianin. Akibat yang ditimbulkan dari mekanisme ini adalah terjadinya tumpang tindih orbital elektron yang menyebabkan antosianin bersifat hidrofobik. Sifat hidrofobik ini menjadikan antosianin sulit terdegradasi oleh akibat interaksi dengan molekul air (Ferreira da Silva et al., 2005); (Trouillas et al., 2016) dalam Nusantara et al., (2017).

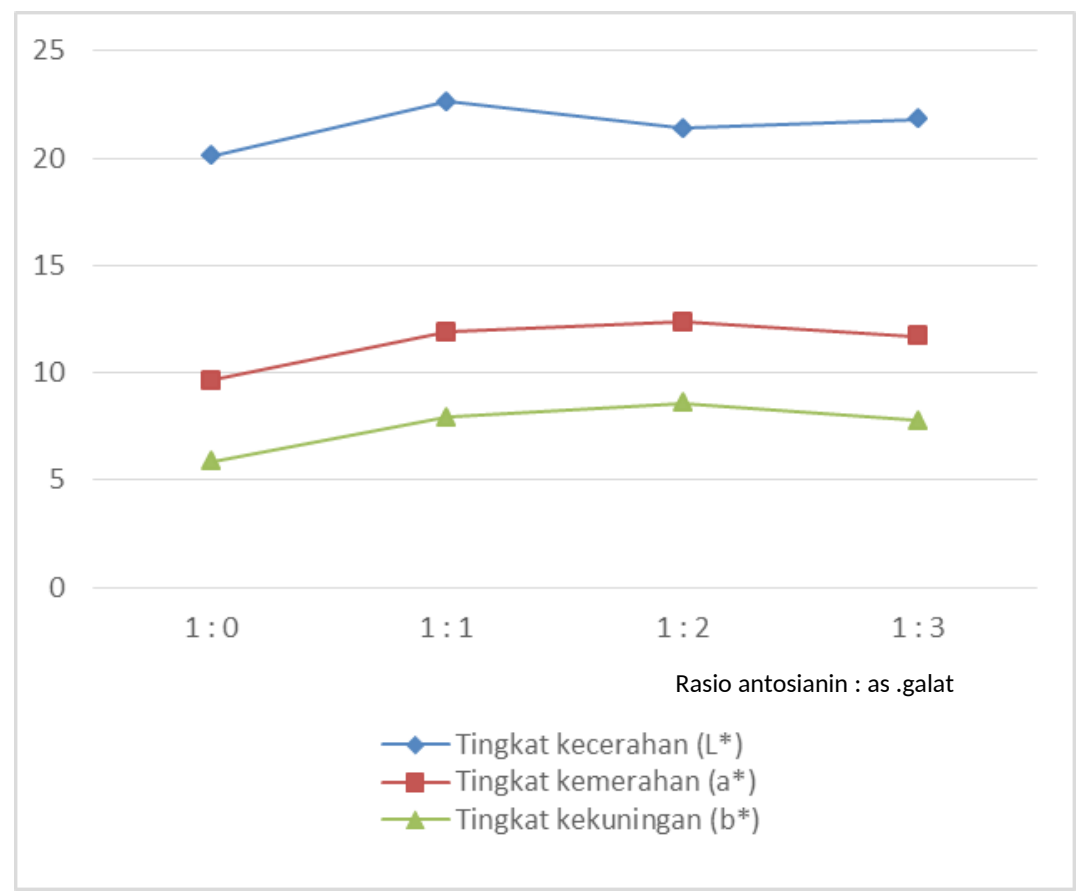

Gambar 2. Tingkat kecerahan $\left(L^{*}\right)$ dan warna $\left(a^{*}\right.$ dan $\left.b^{*}\right)$ antosianin dari berbagai rasio molar bahan kopigmen 


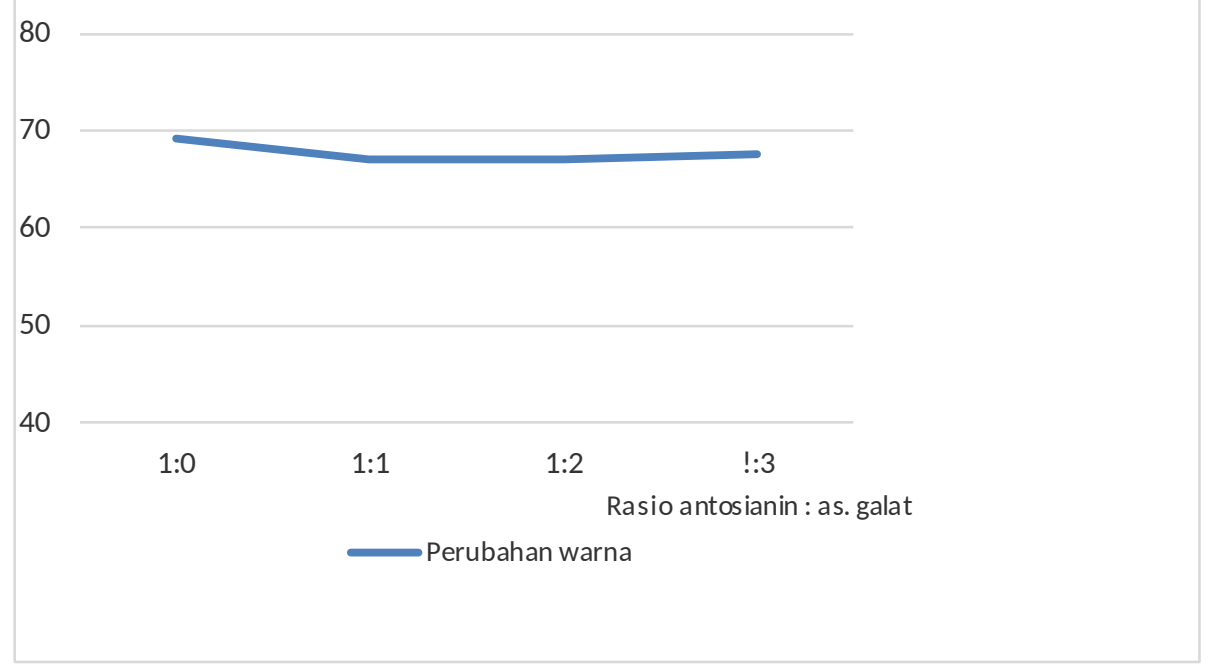

Gambar 3. Tingkat perubahan warna antosianin dari berbagai rasio molar bahan kopigmen

\section{Tingkat Kecerahan dan Warna Antosinin pada Berbagai Suhu}

Hasil analisis kecerahan warna antosianin (Gambar 4) menunjukkan pola penurunan yang tidak mencolok dari berbagai perlakuan kopigmentasi. Walaupun mengalami perbedaan secara tidak signifikan, efek degradasi suhu terhadap tingkat kecerahan warna antosianin terjadi pada suhu $70-80{ }^{\circ} \mathrm{C}$ dan kembali stabil pada suhu $90{ }^{\circ} \mathrm{C}$. Intensitas yang paling stabil dihasilkan oleh antosianin yang kopigmen dengan rasio perbandingan molar 1:1 disusul rasio 1:2, 1;3 dan rasio 1:4.

Melemahnya intensitas warna antosianin dengan rasio kopigmen 1:1 pada suhu $70 \quad{ }^{\circ} \mathrm{C}$ menunjukkan terjadinya degradasi pigmen antosianin sebagai akibat belum optimalnya pemenuhan kebutuhan elektron bebas dari asam galat ke molekul antosianin yang berkekurangan elektron, sehinga terjadi ketidakseimbangan untuk membentuk kompleksitas ikatan antara kedua molekul yang mengalami kopigmentasi. Hal ini didukung oleh pernyataan Castañeda-Ovando et al. (2009) bahwa penggunaan asam galat sebagai penstabil antosianin berkaitan dengan gugus hidroksil dengan elektron yang berlebihan sehingga hal ini memungkinkan terjadinya transfer elektron dari asam galat dengan elektron bebasnya ke flavilium pada antosianin yang kekurangan elektron sehingga membentuk keseimbangan elektron. Selain itu, suhu yang tinggi

dapat menyebabkan degradasi kompleks antosianin yang terkopigmentasi sehingga menghasilkan senyawa kalkon dan turunannya yang tidak berwarna (Cai et al., 1990); (Wilska-Jeszka dan Korzuchowska, 1996).

Kestabilan intesitas warna pada rasio kopigmentasi 1:2, 1:3 dan 1:4 menunjukkan bahwa telah terjadi keseimbangan elektron antara kedua molekul antosianin dan asam galat yang terkopigmentasi sehingga membentuk ikatan kompleks yang lebih kuat. Selain itu, perlakuan dengan rasio perbandingan asam galat yang berlebihan akan berdampak pada perubahan tingkat keasaman antara kedua molekul yang terkopigmentasi, dimana sifat keasaman yang terbentuk semakin kuat sehingga menyebabkan intensitas warna dari perlakuan ini menjadi lebih stabil bila berada pada suhu $70-90{ }^{\circ} \mathrm{C}$. 
Antosianin yang terkopigmentasi dalam suasana asam lemah akan lebih mudah terdegradasi yang menyebabkan penurunan intensitas warna. Warna merah antosianin akan berkurang pada suasana asam lemah, dan bentuk yang paling stabil adalah dalam bentuk ion flavilium pada $\mathrm{pH}$ rendah (Brouillard, 1982). Walaupun tidak dilakukan perlakuan $\mathrm{pH}$ dalam penelitian ini, namun rasio pemberian asam galat sudah menunjukkan kuat lemahnya keasaman dari masing-masing perlakuan kopigmentasi.

Data analisis tingkat kekuatan warna antosianin (Gambar 5) menunjukkan terjadi peningkatan warna merah $\left(a^{*}\right)$ pada rasio $1: 1$ dan 1:4 yang diberi perlakuan suhu $70{ }^{\circ} \mathrm{C}$, sedangkan kedua rasio lainnya (1:2 dan 1:3) mengalami penurunan. Secara umum, keempat rasio perbandingan antosianin asam galat mengalami penurunan warna pada suhu $80-90{ }^{\circ} \mathrm{C}$. Hal ini dapat diduga bahwa pada rasio kopigmentasi 1:1 terjadi degradasi tingkat kecerahan $\left(L^{*}\right)$ antosianin yang berakibat pada timbulnya residu pigmen warna merah sehingga menyebabkan tingkat kekuatan warna merah $\left(a^{*}\right)$ lebih kuat dibanding dengan tingkat kecerahannya $\left(^{*}\right)$ (Gambar 4 dan 5). Sedangkan pada rasio 1:4, terbentuk suasana keasaman yang semakin kuat yang disebabkan oleh porsi asam galat dengan rasio yang lebih besar dibanding dengan rasio lainnya. Akibat yang ditimbulkan adalah terjadi peningkatan efek warna merah $\left(a^{*}\right)$ disertai dengan intensitas yang stabil $\left(\mathrm{L}^{*}\right)$ pada suhu 70 ${ }^{\circ} \mathrm{C}$. Menurut Brouillard (1982), pada suasana asam lemah warna antosianin akan berkurang dan sebaliknya pada suasana asam kuat antosianin berada dalam bentuk kation flavilium yang lebih stabil. Selanjutnya ketika keasaman lemah akan terjadi deprotonisasi dan hidrasi kation flavilium pada antosianin, transformasi stabilitas pigmen yang menyebabkan antosianin tidak stabil (Bridgers et al., 2010). Kondisi ini terjadi pada perlakuan kopigmentasi dengan rasio perbandingan asam galat yang rendah ditunjang dengan perlakuan suhu yang tinggi menyebabkan penurunan tingkat warna antosianin.

Hasil pengukuran tingkat warna dengan efek kekuningan $\left(b^{*}\right)$ (Gambar 6 ), diperoleh pola peningkatan warna terjadi pada suhu $70{ }^{\circ} \mathrm{C}$ dan mulai menurun pada perlakuan suhu $80-90$ ${ }^{\circ} \mathrm{C}$.

Pada suhu $60{ }^{\circ} \mathrm{C}$, rasio $1: 2,1: 3$ dan 1:4, menunjukkan tingkat warna dengan efek kekuningan $\left(b^{*}\right)$ lebih dominan dibanding dengan rasio $1: 1$, namun ketiga rasio ini kembali mengalami penurunan secara drastis pada suhu $70-80{ }^{\circ} \mathrm{C}$.

Fenomena ini menunjukkan bahwa efek kopigmentasi antosianin dipengaruhi oleh rasio asam galat yang berperan menentukan kestabilan antosianin pada suhu tertentu melalui pengaturan keseimbangan elektron untuk membentuk ikatan kompleks maupun suasana keasaman bahan yang dikopigmentasi. 


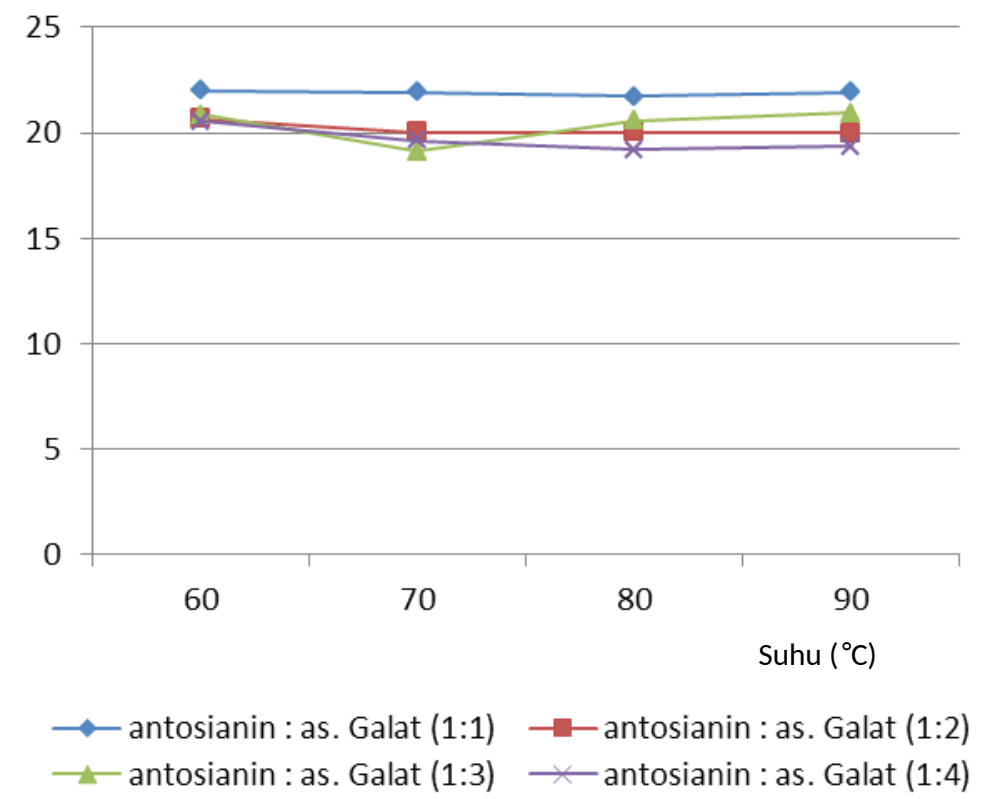

Gambar 4. Tingkat kecerahan warna antosianin pada berbagai perlakuan rasio antosianin: asam galat dan suhu

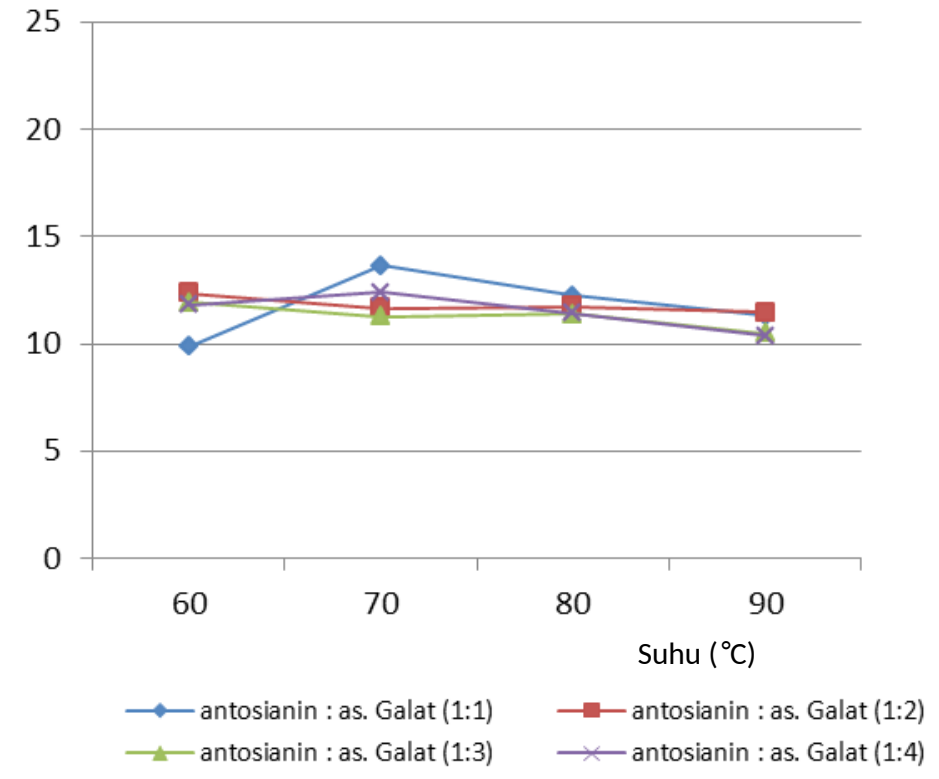

Gambar 5. Efek warna kemerahan antosianin pada berbagai perlakuan rasio antosianin: asam galat dan suhu 


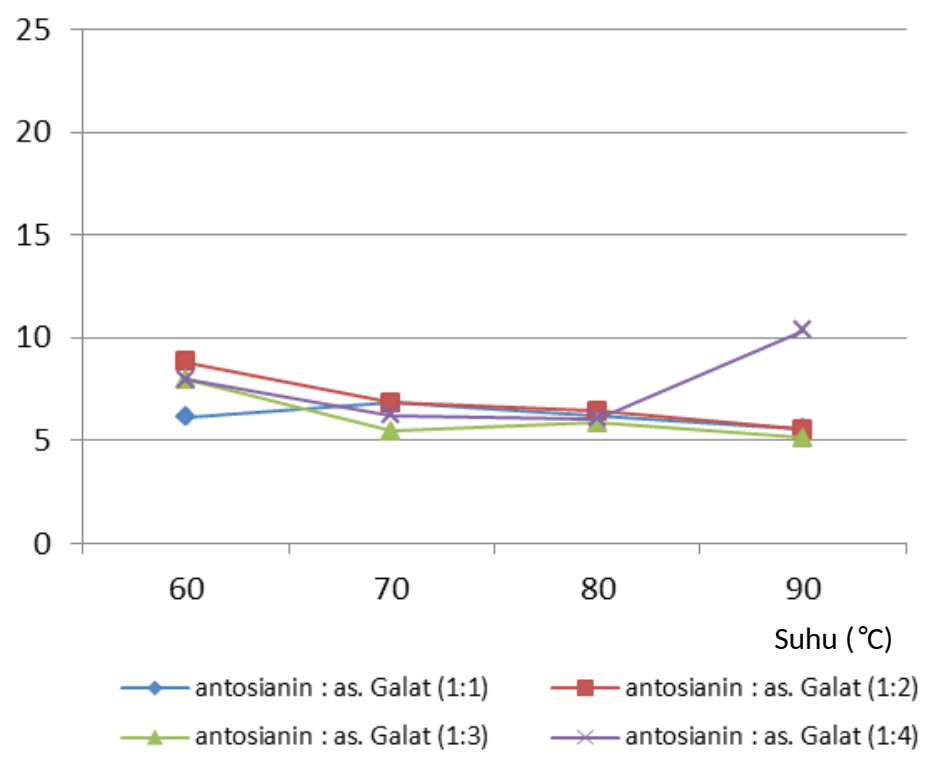

Gambar 6. Efek warna kekuningan $\left(b^{*}\right)$ antosianin pada berbagai perlakuan rasio antosianin: asam galat dan suhu.

\section{SIMPULAN}

Hasil penelitian menunjukkan bahwa kopigmentasi antosianin dengan asam galat pada suhu $60-70{ }^{\circ} \mathrm{C}$ dengan rasio perbandingan molar $1: 2$ dan $1: 3$ dapat mengatasi instabilitas instensitas warna maupun perubahan warna antosianin. Efek kopigmentasi menghasilkan warna dengan intensitas yang tinggi dan stabil dibanding dengan antosianin yang tidak dikopigmentasi. Intensitas tertinggi warna antosianin adalah 0,336-0,387 pada suhu $60-70{ }^{\circ} \mathrm{C}$ dengan kecerahan $\left(\mathrm{L}^{*}\right)$ 22,63 pada rasio $1: 1$. Warna dominan adalah kemerahan $\left(a^{*}\right)$ melebihi kekuningan $\left(b^{*}\right)$ terjadi pada rasio $1: 2$ dengan nilai 12,37 dan 8,6 . Pergeseran warna terkecil $(\Delta \mathrm{E})$ adalah $66,93-67,15$ pada rasio 1:1 dan 1:2.

Kopigmentasi pada suhu di atas $70{ }^{\circ} \mathrm{C}$ menghasilkan efek warna yang lebih kuat dibanding dengan intensitas dan tingkat kecerahan pigmen antosianin.

\section{DAFTAR PUSTAKA}

1. Brouillard, R. 1982. Chemical structure of anthocyanins (Vol. 1). Academic Press:
New York.

2. Cai, Y., Lilley, T. H., and Haslam, E. 1990. Palyphenol-anthocyanin copigmentation. Journal of the Chemical Society, Chemical Communications, 5, 380-383.

3. Castañeda-Ovando, A., de Lourdes Pacheco-Hernández, M., PáezHernández, M. E., Rodríguez, J. A., and Galán-Vidal, C. A. 2009. Chemical studies of anthocyanins: A review. Food Chemistry, 113(4), 859-871.

4. De Man, J. M. 1997. Kimia makanan edisi kedua. Penerbit ITB. Bandung.

5. Delgado-Vargas, F., and Paredes-Lopez, O. 2002. Natural colorants for food and nutraceutical uses. CRC press.

6. Ferreira da Silva, P., Lima, J. C., Freitas, A. A., Shimizu, K., Maçanita, A. L., and Quina, F. H. 2005. Charge-transfer complexation as a general phenomenon in the copigmentation of anthocyanins. The Journal of Physical Chemistry A, 109(32), 7329-7338.

7. Houghton, J. D., and Hendry, G. A. F. 2012. Natural Food Colorants. Springer Science \& Business Media.

8. Hutching, J. B. 1999. Food Color and Appearance Chapman and Hall Food Science Book. Aspen Publishers, Inc., Gaithersburg, Maryland.

9. Lydia, Widjanarko, S. B., Susanto, T. 
2001. Ekstraksi dan Karakterisasi Pigmen dari Kulit Buah Rambutan (Nephelium lappaceum) var. Binjai. Jurnal Teknologi Pangan dan Gizi. 2(1): $1-6$.

10.Markakis, P. 1982. Stability of anthocyanins in foods (Vol. 163). Academic Press, New York.

11. Misnawi, J. S., Jamilah, B., and Nazamid, S. 2003. Effects of Cocoa Liquor Roasting on Polyphenol Content, Hydrophobicity and Astringency. ASEAN Food Journal, 12(2), 103-114.

12. Nusantara, Y. P., Lestario, L. N., and Martono, Y. 2017. Pengaruh Penambahan Asam Galat sebagai Kopigmen Antosianin Murbei Hitam (Morus nigra L.) Terhadap Stabilitas Termal. Agritech, 37(4), 428-436.

13.Samber, L. N., Semangun, H., and Prasetyo, B. 2013. Karakteristik Antosianin sebagai Pewarna Alami. Proceeding Biology Education Conference: Biology, Science, Enviromental, and Learning, 10(3), 6871.
14.Sampebarra, A. L. 2018. Karakteristik Zat Warna Antosianin dari Biji Kakao Nonfermantasi sebagai Sediaan Zat Warna Alam. Jurnal Industri Hasil Perkebunan, 13(1), 63-70.

15.Siregar, Y. D. I., dan Nurlela, N. 2011. Ekstraksi dan Uji Stabilitas Zat Warna Alami dari Bunga Kembang Sepatu (Hibiscus rosa-sinensis L) dan Bunga Rosela (Hibiscus sabdariffa L). Jurnal Kimia VALENSI, 2(3).

16. Trouillas, P., Sancho-Garcia, J. C., De Freitas, V., Gierschner, J., Otyepka, M., and Dangles, O. 2016. Stabilizing and Modulating Color by Copigmentation: Insights from Theory and Experiment. Chemical Reviews, 116(9), 4937-4982.

17. Wilska-Jeszka, J., and Korzuchowska, A. 1996. Anthocyanins and Chlorogenic Acid Copigmentation-Influence on The Colour of Strawberry and Chokeberry Juices. Zeitschrift Für LebensmittelUntersuchung Und Forschung, 203(1), 38-42. 